\title{
should political science be more relevant? an empirical and critical analysis of the discipline
}

john e. trent

Centre on Governance, University of Ottawa, 55, Laurier Avenue East, Ottawa, Ontario, Canada K1N 6N5 (retired)

E-mails: jtrent@uottawa, ca'agentgm_ukn!@yahoo.it

doi:10.1057/eps.2010.65; published online 17 December 2010

\section{Abstract}

This paper arises from the empirical evidence about trends, issues and perspectives in political science to be found in the International Political Science Association's (IPSA) Research Committee 33 book series entitled The World of Political Science: Development of the Discipline and the papers presented at the 2008 Montreal Conference of the IPSA on New Theoretical and Regional Perspectives on International Political Science. One of the issues raised by this analysis of the discipline's strengths and weaknesses is the question of whether political science is relevant to the outside world, and if not why not? It is evident to the naked eye that in comparison with, say, economists (President Obama has three advisory councils), political science is of relatively little interest to policymakers, the media and the public. We have to ask whether political science is out of step with the world, and if so what might be done about it?

Keywords political science; development; advances; reforms; relevance; specialization

I t would seem wise for any serious professional organization to study its entrails every so often to make sure that the portents for its future auger well. After all, it would be more prudent for a discipline like political science to evaluate itself rather than to be obliged to accept the dictates of some unknowing external authority. We would not like to follow the fate of mediaeval monks who were sarcastically asked whether they had discovered how many angels could dance on the head of a pin. Of course, some of us think we are impervious to such challenges because we follow the scientific method.

The World of Political Science Book Series (see Appendix) seeks to evaluate the development of political science. This is not just another 'state-of-the-art' 
exercise. By 'development', we mean analysis of research output and infrastructure, and an explanation of why things are the way they are. We want to move towards the 'causal' understanding of our strengths and weaknesses so we can seek means for improvement as we strive for elusive political generalizations. To do this, we consider political science as our dependent variable for which we seek independent, explanatory variables.

The second source of empirical evidence is a synthesis report I prepared on the papers presented at the 2008 International Political Science Association (IPSA) Montreal Conference on New Theoretical and Regional Perspectives on International Political Science. It brought together leaders of the IPSA Research Committees (RCs) and national and regional associations to discuss the state of political science and its future perspectives. Some 150 participants from more than thirty countries representing twenty-seven RCs and twenty-three political science associations attended. The meeting provided an opportunity to review three ongoing activities: (1) the critical assessment of major sub-fields as reflected by the editors of the forthcoming IPSA Encyclopaedia of Political Science; (2) the organizational review of the discipline, represented by political science associations from every region of the world; and (3) the state of cuttingedge research, as evidenced by the work of IPSA RCs. Of the seventy-five papers, fifty were synthesized in my report for the IPSA Executive. ${ }^{1}$

To put it another way, with the participation of more than 100 authors from the Book Series and the Montreal Conference, this is a very extensive survey of modern political science. While I have to take responsibility for the final analysis and conclusions, when you read the next section it must be remembered that the data, information, primary analysis and explanations, which cover both the infrastructure and research output of the discipline, represent the work of experienced scholars from around the world - with details in the reports cited above.

\section{PART 1: THE DEVELOPMENT OF POLITICAL SCIENCE CIRCA 2010: EVIDENCE FROM THE BOOK SERIES AND THE IPSA MONTREAL CONFERENCE}

Before turning to an analysis of its meaning in Part 2, let us start by summarizing what scholars are saying about political science at the beginning of the twentyfirst century by synthesizing their commentary in a very succinct manner under the headings of 'advances' and 'issues and challenges'.

\section{ADVANCES}

Advances in political science, since the 1980s, can be grouped under five headings: steady expansion of the discipline, the birth of a collective enterprise, eclecticism of research, a leap ahead in methodology and the creation of large data sets.

Geographically, there has been a steady expansion of political science around the world - but not covering the world, as many regimes are opposed to the study of politics. Max Kaase, past President of IPSA, estimates that there are more than 40,000 of us around the world producing 1,000 political science journals. Major expansion has taken place not only in former communist countries and in the Third World, but also in Europe. The IPSA now numbers more than fifty national members most of which can claim a critical mass of political scientists who are adequately institutionalized. In most of these countries, political science is reaching 'adulthood', with the steady 
expansion of departments, associations, journals, professors and students.

The discipline has become a collective enterprise, a profession, with welldefined standards for training and employment, based institutionally in national university systems. Systematic empirical knowledge is growing apace. The profession has established a common language, standards of activity, means of critical assessment and generally well-established professional communities including research networks. Internationalization through associations, exchanges, publications, and research projects and networks has led both to better professional standards and homogenization.

There are also a number of common tendencies concerning content. The core components of the political science curriculum that Klingemann attributes to Europe apply more broadly across the world. They include: political theory and history of political ideas; political system of one's country and the region; public administration and policy analysis; political economy and political sociology; comparative politics; international relations (IR); and methodology. However, different epistemological positions surface when it comes to methodological skills: one camp stressing analytic theory and quantitative data analysis while the other prefers a philosophical/historical approach and hermeneutics.

A global set of research sub-fields seems to be appearing, focusing on a myriad of research specializations (IPSA has fifty RCs; American Political Science Association (APSA) and the British PSA have $30-40$ sections). The fields most often mentioned are national political systems, democratic regimes, methodological approaches, area and comparative studies, international politics, public administration and local government. For instance, a recent APSA study of major fields of political science research in the United States showed that 38 per

\section{'Research output may be characterized as diverse and eclectic ...'}

cent worked in American politics, 37 per cent comparative, 30 per cent IR, 17 per cent political theory or philosophy, 10 per cent public law and 10 per cent methodology. There is also a convergence around an eclectic, pluralist set of approaches to political analysis. Among those mentioned on several occasions: systems analysis, structural-functionalism, behaviouralism, historical-institutionalism, juridical-constitutionalism, critical theory, Marxism, feminism, public management, rational choice, constructivism and interdisciplinary analysis. Convergence in journals is towards: the internationalization of authors and contents; thematic and specialized journals with fewer generalized ones; less influence for nonEnglish journals; more methodological and empirical maturity and complexity of content; less parochialism, more comparativism and international studies.

Research output may be characterized as diverse and eclectic - perhaps reflecting the vast range of subject matter the discipline must cover. As indicated by the IPSA RCs, the research covers all levels of politics - local, regional, national, international and global. Most work is Western, with growing amounts from Central and Eastern Europe and the Developing World, as well as broad comparisons. Approaches include institutionalism, processes, individualism, belief systems, markets, comparison and multi-level governance. There is a reaching out to other disciplines and concepts such as biology, evolutionism, morality and history. We have a new appreciation of the impacts of globalization, including its complexity and multi-level, multi-actor influence. 
Issues attracting attention include: health care, family structures, sexuality, welfare, domination and imperialism, religion, fundamentalism, terrorism, democracy, parties, legislatures, participation, political finance and corruption, ideologies, policy networks, political culture and the digital divide. Each study has significant findings, but are they communicated to interested publics? Among newer research trends are large data sets, multi-level governance, biological evolution, local impacts on change, institutional evolution, a return to problemoriented and actor-oriented research, and a greater appreciation of historical sociology and normative theory. This is only a sample and is not a systematic portrayal of the discipline. Notably, only a minority of the studies makes policy recommendations. The majority of the papers are addressed to the discipline.

Preliminary papers for the IPSA Encyclopaedia covered some of the fields attracting major attention. After decades of studies, elite theorists have some unpalatable advice for their fellow citizens. Elites arise from the fact that in large collectivities common interests are fairly minimal and must be supplemented by authoritative decisions. Historical evidence indicates that no type of elite is compatible with the full democratic ideal. New Public Management has proposed the adoption of private management techniques in government settings, as well as outsourcing, privatization and 'letting managers manage'. Both elite and governance theorists recognize the functional need to provide collective decision-making steering. The main difference between government and governance is the extent to which nongovernment actors - interest groups, corporations - take part in the process. The list of variables in policy analysis typologies, policy fields, comparison, policy instruments, legislation, issues, discourse and social factors - keeps getting longer and our understanding more complex.

There have been great advances in research techniques and information sources. The study and application of methodologies, especially quantitative ones, have made great leaps forward. The level of sophisticated quantitative analysis is 'stunning', as is its interpretation. This is supported by advances in norms and software for the collection, replication and sharing of large- $\mathrm{N}$ data sets. There is also tremendous interest in working out research design issues. One particular advance is in new multilevel models that allow researchers to get beyond assumptions of homogeneity by both assessing and modelling heterogeneity and by aggregating micro and macro analysis.

Political science now has a number of large international data sets that contain dozens of key variables, indexes and classifications that allow easier comparison of countries on both a static and dynamic basis. They also help us place countries on a continuum concerning international issues such as the quality and the efficiency of the state, capacity to respond to threats, capacity for influence, public well-being and democratic potential. There are also many more elaborate statistical data archives, information banks, values surveys, barometers, indicators, audits, newsletters and websites to help us study public opinion, voting, decision making, conflict and negotiation etc.

\section{POLITICAL SCIENCE ISSUES AND CHALLENGES}

Once again we may group under several headings the issues and challenges facing political science. These are: the viability of research paradigms; tensions between objective and normative approaches; keeping up with global change; Western and male predominance; making political 
theory reflect society; the fragmentation of the discipline; tendencies towards excessive specialization; and relevance of politics, the media and the public.

There has been a continuous output of research and new models and theories. But almost all the political science research paradigms are severely questioned. The major conclusion has to be that there have been no major breakthroughs, and even the purportedly significant changes are all now hotly contested. To give but a few examples:

- The question is posed of whether all the more sophisticated methodological analysis is too far out in front of the discipline? Should political science not seek coherence between theory and methodological measurements? Perhaps there is too much emphasis on maximizing the internal validity of our quantitative models at the expense of external validity and generalizability to the world of politics.

- Despite purported qualities of generality and parsimony, rational choice theory was generally condemned. It is of limited value unless incorporated in broader descriptive realism. Assumptions of rationality, full information and utility maximization are unrealistic.

- There are four critiques of 'governance': (a) it has many meanings and does not give a central role to government; (b) the concept is derived from descriptions, and has no theoretical argument; (c) it is likely that nongovernment bodies have always been involved; and (d) cases are limited to Western liberal democracies.

- IR is still mainly 'a Western project'. But even within the 'Western' region, there is a growing perception that the prevailing Westphalian idea of statehood does not grasp current processes of transformation. Some researchers are calling for a 'debordering' of the discipline to develop a 'science of the global' that seeks to distance itself from 'methodological nationalism'.

There are similar deep criticisms of most of the other recent focuses of the discipline.

Tensions between objective and normative approaches are endemic. There is a mainstream/non-mainstream division and deprecation between quantitative (e.g., empirical/scientific) versus qualitative (e.g., philosophical/institutional) practitioners. Tensions run deep between 'scientific' and 'political' orientations; 'value neutrality' and 'doing good'; and between experimental, causal certainty versus the validity of external reality.

It is often posited that the mainstream quantitative empirical approach is mainly responsible for the current impression that political science has become irrelevant and cannot deal with the real world of politics. Even so, we should never say never. In an article in The Future of Political Science, Bear Braumoeller argues, 'At the same time, advances in statistical methodology are opening a back door to thinking about synthesis and complexity. What are hierarchical models, Boolean models, and simple multiplicative interactions if not models of context? ... Still, these issues tend to be treated as a nuisance to be eliminated, rather than an opportunity to formulate a richer and more satisfying description of social reality' (Braumoeller, 2009: 242). But some day ...

Keeping up with global change is a real challenge for political science. If we are able to arrive at generalizations concerning worldwide political science, it is likely because we are all facing a more demanding, increasingly competitive, homogenizing environment. It is therefore not surprising that despite great expansion and research development, rapid global changes is another reason for our reduced understanding of current politics. 
A common perception stresses the significant influence of change on the political science agenda from the end of the Cold War to the $9 / 11$ attack on America and the processes of globalization, and international mobility. There is an absolutely enormous scope of issues confronting modern society and, by extension, political science. The scope of issues is augmented by simultaneous demands for more attention to human values and identities, interdisciplinarity, a global vision, and being relevant.

Far from reflecting national or international communities, political science is still predominantly Western and male. Even the most advanced political science communities reported that barely a third of political scientists are female, but the share is a little better for the new cohort. In multiethnic and multiracial Western countries, the non-white groups, especially aboriginals, are poorly represented. Youth are also having difficulty getting into the discipline due to budget cuts and a loss of popularity in some places that creates congestion on the career ladder.

The profound global changes just noted also make it increasingly difficult for political theory to reflect the world. In a globalized world, how do we reconcile equality and universality, common identity and new particularities? How do we define new forms of solidarity? Theory will have to deal with the rediscovery of history and religion. Again we must ask, what are the meaning and limits of universal and regional concepts? The conundrum will be developing broad theory in a world of cultural and local differences where shared values often do not exist. There is a similar dilemma in finding the right mix of the normative and the empirical, the 'ought' and the 'is'. Political theory should be based on a conversation between the classical and empirical approaches rather than their isolation from one another by mutually suspicious specialists.

\section{'Political scientists ... recognize their discipline has little relevance for politics, the media or the public ...'}

Many political scientists deplore the increasing fragmentation of the discipline. Principally, they question the bifurcation of the discipline into 'IR and the rest', when it is becoming increasingly difficult to distinguish between the 'domestic' and the 'international'. The same can be said of public administration, which, like IR, often has its own departments and associations. Surely the logic of politics does not stop at national frontiers or at the antechambers of government. Fragmentation leads to the blurring of the discipline's boundaries and its representation.

Another major concern is the excessive specialization within political science. Most researchers are drawn into ever narrower fields of research, often with their international colleagues, while ignoring local issues. While some British and Americans see specialization as a boon, providing links to non-academic interests, others fear divisions are being created that impede effective communication, prevent cumulation, hamper debates within the discipline and reduce our capacity to deal with political reality.

Political scientists from many countries recognize that their discipline has little relevance for politics, the media or the public, thus leading to issues of visibility, recognition, relevance and identity. The Americans recognize allegations of 'monolithism, scientism and detachment' and wonder whether there has not been an increasing risk of 'scholasticism and detachment from practical politics'. To put it another way, there is a retreat from domestic political debate because of our 
specialization and our 'scientific pretensions'. There are few 'public intellectuals' and few connections with the political class. Several countries (e.g., UK, Belgium, etc.) reported strong interaction between academics and policymakers, but most countries complained of poor applications of our research to politics and poor visibility in the media. Others are dependent on state contracts, research funding and authorizations. The general result is a widening gap between public expectations and scholarly interests, and a sense we are not helping citizens. In addition, political scientists in some countries have weak visibility in comparison with journalists and other disciplines that traditionally have disputed the subject matter (law, history, philosophy, economics and sociology).

\section{FURTHER DEVELOPMENTS}

Among the most striking recent trends in political science is the 'change and diversification' reported by the United States. While most other countries are trying to catch up with US scientific orientations and quantified, empirical methodologies, the Americans are starting to realize their limitations. For instance, the newest organized sections in the APSA go against international trends. One of the largest of them deals with 'qualitative and multi-methods'. Furthermore, projected American research trends deal not with the core topics mentioned around the world, but with feminist theory, the study of identity (race, nationalism, ethnicity, sexuality, personality, etc.), and the integration of theoretical and empirical models, among others. Even more radically, the APSA projects that their discipline will grow in its awareness and attention to public issues. There is also a noticeable return of values and norms. The APSA Report on Graduate Education suggests a revolutionary new ethic for political

science that goes well beyond the traditional 'science for knowledge' motivation. The APSA Report says that one of the discipline's primary tasks is the 'exploration of how far politics can help explain human experiences and help resolve human difficulties' and that 'studies of ethical norms and normative commitments are central to the study of politics'.

\section{PART 2: COMMENTARY: FUTURE PERSPECTIVES}

\section{THE ISSUE OF RELEVANCE}

The overall impression one gains is that the discipline has been developing in an incremental manner during the last decade of the twentieth century and the first of the twenty-first century. As we have seen, there has been a steady expansion of political science around the world; an increase in its depth as a collective enterprise and profession; improvements in empirical methodology; and a flowering of research models. Nevertheless, political science around the world still seems to be looking for itself. In fact, what was said of IR seems to apply to all of political science: the community has rejected 'great debates' and settled down for Kuhnian 'normal science', each researcher 'self-encapsulated' within one of a broad range of coexisting theoretical perspectives. It has been called 'analytical eclecticism' based on a selfconsciously 'agnostic methodological stance'. The basic impression is still one of a discipline in search of its soul and out of touch with the real world of politics.

In Part 2 then, we proceed from empirical description to explanatory analysis. This part turns to the analysis and criticisms of the current state of political science drawn from the authors in the Book Series and the Montreal Conference. The focus is on the two 
major weaknesses that stand out in their analysis: a lack of relevance of political science to the outside public and considerable over-specialization that hampers the capacity of the discipline. The final section turns to conclusions about the future of political science that I think we can draw from this material.

As one example of the rejection of 'great debates', we may refer to the fiftieth anniversary presidential address that Thomas Weiss made to the 2009 International Studies Association Convention in which he contrasts notions of world government and global governance. While global governance is a useful heuristic device to understand what is going on in the world, it lacks prescriptive power to point to where we should be headed, and where agency and accountability are absent. Turning to the concept of world government, Weiss (2009: 256) maintains, 'We analysts of international organizations have strayed away from paradigmatic thinking. We have lost our appetite for big and idealistic plans because so many previous ones have failed'. Therefore, blame can be apportioned to scholars for their lack of imagination. He says, 'It is humbling to realize how much our aspirations have diminished, how feeble our expectations are in comparison with earlier generations of analysts' (ibid.: 264). Even worse, academic analysis can have a harmful effect because 'pragmatism also reflects an assumption that no powerful global institutions will appear any time soon, a self-fulfilling prophecy of sorts' (ibid.: 264). He calls for more passionate advocacy, vision, a quantum shift in thinking.

As we have seen, two common themes in our body of evidence on the development of the discipline are the significant influence of change on the political science and the lack of representativeness of the discipline. The two are linked. One can safely claim there is no end in sight of challenges to security, the envir-

\section{'... is political science out of step with the world?'}

onment, equality, democracy and economic stability. And yet, we are limited by the realities of the sociology of science, which, it is said, are based on the dominance of national disciplinary structures that are self-absorbed with research agendas that reflect national conditions including male dominance and tend, at the most, to still be Western.

What is the current perspective from which political scientists will be able to deal with these challenges? We have seen the lengthy list of problems that face the discipline. But, is there not also a serious disconnect between political science, politics and the public? Are we listening to politicians and the media, and do they listen to us? Do we address ourselves to the general public? In short, is political science out of step with the world?

As we have just seen, many people fear that our excessive specialization, our refusal of 'great debates', our penchant for 'normal science' and our 'lack of imagination' reduces our capacity to deal with real political issues. Many writers were concerned about answering these issues of visibility, recognition, relevance and identity. The Americans recognize allegations of 'monolithism, scientism and detachment'. We noted that most of the papers on the 'cuttingedge' of the discipline were addressed mainly to other political scientists. Political science has few 'public intellectuals' in its ranks. It was even maintained that there is a widening gap between public expectations and scholarly interests. Simply put: is political science relevant? Unfortunately, the question is not so simple because it begs the question of what one means by 'relevant'? 
The concept of relevance begins with a relationship to a consequential other. With what significant audiences should political science be connected? More or less obvious answers are: other political scientists, citizens, politicians, policymakers, specialists, educational authorities, research funders, and, of course, students. Political scientists have multiple roles as teachers, researchers, administrators, specialists, consultants, advisors, employees and commentators. Being relevant to all these roles and audiences makes diverse and sometimes contradictory demands on political scientists.

To go one step further, we may ask whether political scientists, because of the nature of their unique profession, do not also have a requirement to go beyond strict professional obligations to include such weighty qualities as being wise, balanced, far-sighted and critical. The main debate is with regard to audience. Some will maintain that our main obligation is towards the discipline, that is, to the production of more and better knowledge. In his book entitled, from Knowledge to Wisdom: A Revolution for Science and the Humanities, the philosopher of science, Nicholas Maxwell, contends that intellectuals must do better. They must have as their basic aim to enhance personal and social wisdom. They have to give priority to personal and social problems, to what is desirable and of value. He makes a fundamental critique of the underlying empiricism of the philosophy of knowledge. Further, problems of knowledge, while important, become intellectually subordinate and secondary. Thus, knowledge is a tool to an end. In such a context, one would have to argue that the relevance of political science goes beyond the discipline and policymakers to include citizens, the media and society. This is what I mean by relevance. I assume that political scientists will always have to continue to be relevant to students, educational authorities, research funders and policymakers because they give us our mandate and our salaries. But in a more profound sense, it is the public and the political class, society and democracy, to which political scientists must be responsible.

Admittedly, we must be very careful when we use a term such as 'relevant'. This is not a call for turning universities into trade schools or changing professors into functional sycophants. Nor is it a desire to see each individual researcher being hauled before the bar of popular culture or political suitability. Rather it is a claim that the political science profession as a whole has a social responsibility that includes, but goes beyond, empiricism and the search for knowledge. The discipline, or at least a significant proportion of it, must be pertinent to students and their liberal education, but also to public issues and the future as well as the present. As Oscar Wilde wrote, 'A map of the world that does not include utopia is not worth looking at' (1954/1891).

How are we currently dealing with the issue of relevance in political science? Already, the Americans are working to enhance the discipline's awareness and attention to public issues. Nevertheless, a more fundamental solution might be to look at how our research is produced and what rules it follows. Is it not possible that the difficulties we have connecting with a broader public are, in part, due to our scientific methodology? The Book Series posed a number of questions in this direction.

\section{Disciplinarity}

Does not a too narrow concentration on politics cut us off from fields of knowledge that is essential to our research? Are not political issues interdisciplinary by their very nature? As Parsons and Easton taught us, we have to develop methods that include the social, the economic, the psychological, the philosophical and

john e. trent european political science: 102011 
the international - not just one of these, but all of them in an integral manner. One example: Laurence Whitehead (2007: 131 ) says in the book on Democratization that Guillermo O'Donnell's work on 'delegative democracy' 'is a prime example of scholarship inspired by the turmoil of learned experience, rather than constrained by orthodox disciplinarity'.

\section{Scientific}

Is the scientific method too constraining for the study of politics? As long as science means searching for the rigorous, viable and verifiable means of knowledge, it is an aid to the study of politics. But when it becomes pure methodologism, computerization and quantification, does it not constrain the analysis of the complex diversity that is politics and government? In Political Psychology (Linda Shepherd ed.), there is a fascinating article on computational, experimental (i.e., laboratory) and data set approaches to the study of foreign policy decision making. While quite positive about the benefits of the studies, Sylvan and Strathman (2006: 96) nevertheless also note that computational and specifically hermeneutic models 'do not directly address "real world" political concerns, but rather engage in academic discourse ... do not take particular, defined bodies of knowledge or social structures as given ... they do not attempt to explain the outcome of specific decisions ... its failings lie in its explanatory power ... they disappoint those who seek policy relevance'. After such a litany, can we expect politicians to listen to us or pay for our work? Should we not be concerned that quantitative scientific methodology only lends itself to a small portion of the political world?

\section{Empiricism}

Have we not all been brought up in our graduate studies to recognize that strict adherence to empiricism can lead to conservative conclusions? Empirical research only deals with what exists. It does not include what could be or what should be.

\section{Value neutrality}

Is it possible to explain political behaviour, or policies without taking into account human values or the values of the researcher? Linda Shepherd, editor of the volume on Political Psychology, concludes that 'The attempt to define the interplay between politics, morality, philosophy, and human nature can certainly animate a research agenda' (2006: 133).

\section{Tentativeness}

Do we not teach our students to be very tentative about the results of their research, and does this not stop them from taking the 'leaps of faith' that might allow them to make contributions to the decisions that are necessary in complex and turbulent times? As one anecdotal example, an excellent piece of empirical research at the ISA 2008 conference demonstrated conclusively that international organizations, and not governments, were responsible for more than 80 per cent of treaties and conventions, thereby single-handedly rejecting Bush's claim that the UN is irrelevant. Yet the study's conclusions were framed in the sense of 'suggestions' that 'perhaps' a 'relatively' large number of international solutions came from these defamed international organizations.

All of this leads to the question: do our political science research methods not lead us to results that are too narrow, irrelevant and tentative to be taken seriously by those who should be consuming our product? In a recent volume (Shapiro et al, 2004) on Problems and Methods in the Study of Political Science, political science is portrayed as a battlefield of highly disparate agendas, worshipping conflicting ideals of 
scientific endeavour. The main conflict is between problem-driven research versus champions of methods- and theory-driven studies. Real-world relevance and eclectic methods confront analytical rigour, explanatory elegance and the goal of a unified science. In the same volume, Robert Dahl et al opt for seeking 'to help achieve good ends' rather than the goal of a unified science (378-381). In the Book Series volume on Local Government, Baldersheim and Wollmann propose an alternative approach that combines problems with theory orientation in a sort of return to Harold Lasswell's famous programme for 'policy sciences' that is both scientifically sound and of practical relevance.

I am not suggesting that we throw the baby out with the bath water. The scientific method has helped us to think about rigorous knowledge. But it excludes many domains like philosophy, law, governance, democracy, nationalism, religion, morality, equity, values, goals, constitutions, etc. Do we not need a new form of analysis that allows us to deal rigorously with all the enormous issues that confront us in the twenty-first century? The authors in our Book Series have answered positively. O.P. Dwivedi (Governing Development) proclaims, 'My view is that the new century demands a new thinking to face the greatest dilemma before humanity: how come a small group of nations keep on 'progressing' while the majority remains poor and deprived (184)? Juan Linz (Democratization) states, 'The task ahead is gigantic and a few cross-national surveys are far from sufficient for our needs' (145). And Geraldo Munck adds, 'Indeed, the future development of the research agenda on democratic transitions is likely to hinge on the ability of scholars to tackle some broad and fundamental challenges' (2007: 51).

There have been a number of suggestions to help political science combat its poor relations with the public and the political class, and to improve its analysis of real political problems. Several proposals were made for the creation of dedicated think tanks to bring scholars together in new cross-disciplinary and policy-oriented ways. More fundamentally, political scientists need to make a collective effort to understand the social needs of their time. Relations with politicians and governments should be constructively critical, engaged, but autonomous. Broader perspectives in the M.A. programmes might counteract hyper-specialization. We also need to have better information on the infrastructure and institutionalization of the discipline.

I am not sure that any one of us alone, or even working in our departments and associations, can come up with solutions to these fundamental problems. Political scientists have to learn to think collectively. Thus, my last question is this: should our national political science associations, regional associations such as the ECPR, and the IPSA not be setting up one or more commissions to study and evaluate the state of the discipline and propose techniques for its development?

\section{DEALING WITH SPECIALIZATION}

We have seen that among the most significant issues facing political science circa 2010 are the problems of fragmentation and specialization. Of course, these are intimately related to the scientific method just discussed. Fragmentation encompasses all the divisions in political science that have been mentioned in our evidence - the separation of IR and public administration and some other sub-fields, competing theoretical and methodological approaches, and a myriad of other splits over language, centre versus periphery, ethnicity, country-specific education systems, etc. Specialization is another form of fragmentation. By specialization, 
I presume we mean individual and group concentration of research within one of the academic sub-fields of political science. While not disputing the contributions of specialization, several authors worried that it has become 'excessive'. By this, we may presume they have in mind scholars whose research focuses on ever-more narrow subjects that absorb their whole career and generally exclude any attempt at linkage with other subfields or with social problems.

It cannot be doubted that the power to concentrate on a subject has led to many of the breakthroughs in science. The capacity to know all about a specific research area, to be in contact with colleagues at the cutting-edge of the field, and to focus one's research on new developments can offer inspiration and save time and energy. Specialization is an integral part of scientific progress. The questions are whether specialization also leads to human progress and whether its excesses can be counteracted? It seems that each time we learn of a new scientific advance, we also hear about examples of related, uncontrolled technologies despoiling our environment and communities.

Authors of the papers in my report enumerated some of the problems that excesses in specialization are causing for the discipline:

- Camped in their narrow fields, political scientists communicate badly.

- Narrow, academic knowledge does not help public understanding.

- In the discipline there is little theoretical debate among the 'separated tables'.

- Students are rarely encouraged to 'look at the big picture'.

- Specialization with foreign colleagues distracts from debates at home.

- Hyper-specialization especially affects quantitative-qualitative internecine conflict.
- Many fields and paradigms are in fact more complimentary than competitive, yet they tend to ignore each other or press for primacy instead of cooperation.

The question is, of course, can anything be done about fragmentation and particularly about specialization, or is it just the nature of the beast? Specialization is all encompassing and has been around for a long time, and thus we have had some time to think about it. Nevertheless, the problem is so all-pervasive that it will take the determination of the whole discipline to deal with it - another reason for creating the political science study commission called for in the last section. There are already signs that disciplinary leaders have recognized the extent of the problem. The IPSA has always taken care to start its World Congresses with Main Theme Sessions that bridge the discipline. Now it has taken responsibility for organizing cooperation and communication between RCs. In the United States, political scientists are seeking new means for promoting inter-sectoral and interdisciplinary research. More and more voices are being raised against the irrational divisions between political science, IR and public administration. Perhaps someday the executive committees of the IPSA and the International Studies Association will meet together to study how, once again, IR specialists may feel comfortable in the general discipline.

But, it is likely that much more needs to be done to build a holistic understanding of politics. It is unlikely either that specialization will disappear or that any single solution can be found for its excesses. Rather, we need to think in terms of spreading awareness of the dangers of specialization and taking counter-active measures. Should there be obligatory introductory courses and texts dealing with the major issues in politics at the 
B.A.? Should our doctoral students be encouraged to cooperate and tackle fundamental issues facing our societies? If political scientists take greater responsibility for developing expertise on current social problems, could there be greater interaction with politicians and public servants? We might start with our annual conferences. Indeed, our associations might seek creative ways to bridge the gaps between our discipline, the media and the general public. Have we ever proposed media seminars on public issues or offered the media-easy contact with experts on hot topics? In addition, political scientists will have to accept more responsibility for effective communication of their own research, and learn how to deal with the media. Perhaps, at a minimum, we should strive to ensure that narrow specialization is not considered to be a scholarly attribute.

\section{CONCLUSIONS: LOOKING AT THE FUTURE OF POLITICAL SCIENCE}

While I firmly believe in the need for a global commission for the evaluation and the development of political science, it would perhaps be irresponsible of me to conclude (after all this descriptive analysis) without asking what this study suggests in a prescriptive manner about the future of the discipline.

First, let us recapitulate. We have seen fundamental criticisms of political science approaches, methodologies and theories. Scientism as a basic approach for political science is seriously flawed. It helps little, or not at all, with a great deal of the subject matter of politics. Value-free politics is an oxymoron. Empiricism keeps us in a status quo straightjacket that ignores the future. Concentration on 'facts' begs the question of what are political facts. The internecine struggle between quantitative and qualitative

\section{'Scientism as a basic approach for political science is seriously flawed'.}

methodologies hobbles our productive capacities. Restrictiveness within disciplinary boundaries inhibits us from comprehending the broader context of politics. Intensive specialization compartmentalizes knowledge and scholarship. Most political scientists do not believe they have a responsibility for communicating with the public. A discipline dominated by white men and that does not span the world inevitably loses out on its breadth of comprehension. Being severed from IR and public administration makes political science a seriously handicapped discipline. We are of less and less interest to the public due to our focus on the pure production of knowledge and general rejection of participation in the 'great debates' of society. This also minimizes our capacity to deal with the immense scope of change going on in a globalized world. All of these deficits, taken together, are responsible for political science being of little public visibility and relevance. Their cumulative effect ensures a widening gap between public expectations and scholarly interests. To improve our research output, it would appear we must go back to basics.

But all the news is not bad. Political science has expanded dramatically in recent decades. As educators, we have adopted a judicious and attractive curriculum around the world. An introductory post-secondary education that includes not only an understanding of our own society, but basic knowledge of several relevant disciplines, comparative knowledge of many countries, and also historical, international, philosophical and methodological perspectives, appears to be of interest to many students. If we

john e. trent european political science: 102011 
may surmise that education is 50 per cent of our output, then it is a very healthy base for the discipline. We are now also a recognizable, international discipline and profession with common standards. Over recent decades, there has been a convergence around an eclectic, pluralist set of approaches to political analysis. Systematic empirical knowledge (e.g., data sets) is growing apace. Our sources for this study indicate that we produce much more information, significant findings and cogent advice than is ever effectively communicated to the public. The fact is that we now know much more about most of the elements of politics than ever before. There is little virgin, unexplored territory in political science. This is one of the reasons why it is so difficult for any one of us to intimately know the entire discipline. But this achievement has come at the cost of an understanding of the whole - that is of the articulations between the elements of politics.

It would seem that our main difficulties are with the theory and research side of the discipline, rather than our teaching. Of course, this is not the first time that political scientists have concluded that their research needs improvement. Before looking to the future, we need to caution ourselves by remembering what it was we criticized about the discipline some 60 years ago at the start of the behavioural revolution. We do not want to forget where we have come from. At that time, it was thought that there was too much historical rumination, too culture-bound, too much description of governmental institutions and too much dependence on emotion, fait or tradition. Simultaneously, there was too little rigorous, scientific methodology, too little analysis of political behaviour, too few universal generalizations and too little systematic theory (Easton, 1953). Unfortunately, as in all revolutions, we forget the limiting adjectives ('too much', 'too little') and throw the good out with the bad. In an extreme turn-around, the criticism becomes the new orthodoxy. Even so, the lesson is that it is not sufficient now to demand that we bring back all the traditional elements of political studies or that we eradicate the developments in the discipline of recent decades. What is called for is a rebalancing.

To seek improved research and heightened relevance, we need to go back to the basic problem of relevance. The basic questions are: what is political research, why do we do it and for whom? Obviously different people will offer different answers. For brevity, let us say we study politics because it is the second most important set of actions affecting human affairs. Traditionally, it is said that politics is the study of the process of making binding decisions ('authoritative allocation of values') for a total population (Max Weber via Easton, 1953: 129-133). If we think of the allocation of values in terms of the 'funnel of causality' concept from the American Voter, we can imagine a process that has a broad societal scope at different times, but gets narrowed down towards the decision-making point. Nevertheless, Angus Campbell et al (1960) insisted on the researcher's need for a grasp of the total situation within the context of the larger political system and historical setting and the field of analysis that, in their case, they saw as the juncture of political science, sociology and psychology. This example indicates that our research must obligatorily be informed by knowledge of relationships between the main fields of social studies and an understanding of time and space to provide the required context. As students, we must be given an understanding of the theory and practice of the 'big questions' of global history and politics.

But the 'why' has broader ramifications for our specialized field of studies. For each specific research, we start by rigorously 
specifying the question we are analysing - the dependent and then the independent variables. Then we should be asking ourselves whether our goal is description and/or explanation, prediction or prescription (DEPP for short). Today, too many of our methodologies lead only to glorified descriptions. For instance, in an essay entitled 'Why', Kenneth Shepsle (2009) argues that, 'We learned to count, measure and generally to identify regularities and give precision to otherwise imprecise observations. But we forgot, for quite a long time, how to ask "Why?"... Explanations for empirical regularities, carefully derived from clearly articulated premises, are the gold standard to which we should hold ourselves' (p. 244). This signifies that we must think carefully about the objectives of our research (beyond simple description) and tailor our work to those ends.

'Why?' also implies that we must ask ourselves what is the audience for our research? Research is not undertaken in a vacuum. To whom do we have an obligation? There are multiple answers. A part of our work may be for the development of knowledge and is addressed to the discipline. But surely it does not end there. The development of the discipline is also aimed at those who pay our bills, our funders. They too are an audience representing the public good. In addition, an understanding of politics is generally for the public, the political class, the media, and, certainly, our students. When we structure our studies, we should have in the back of our minds our potential, multiple audiences, and we must be enquiring whether we are adequately communicating with them. If we have multiple audiences and obligations, then the end goals must include, but go beyond, the pure production of knowledge. I agree with the critics of the strict scientific approach, such as the American Commission on Graduate Education, that
'... political science must take responsibility for developing expertise on society's major issues'.

the study of politics must deal with explaining human experience and helping to resolve human difficulties and that the study of ethical norms and normative commitments are central to the study of politics. Or, as the philosopher of science - Nicholas Maxwell - puts it, political science must have as a basic aim the enhancement of personal and social wisdom and giving priority to personal and social problems. In short, political science must take responsibility for developing expertise on society's major issues.

To the degree we can agree that these objectives currently are not paramount for most political science research, we must ask why is this so? The opening, major paragraph of this section spells out the multiple reasons developed among our 100 authors. Principal among them is the critique of the scientific method and over-specialization. But this criticism has gone on for several decades (e.g., Andreski, 1974; Maxwell, 1984/ 2007; Ricci, 1984; Lindblom, 1992; Flyvbjerg, 2001; Paquet, 2009). To try to get at the root of the matter, let us say that the discipline has ignored David Easton's plea in his path-breaking book, The Political System: an Inquiry into the State of Political Science: 'A major source of the shortcomings in political science', he wrote, 'lies in the failure to clarify the true relationship between fact and political theory and the vital role of theory in the relationship .... . In and of themselves facts do not enable us to explain or understand an event. Facts must be ordered in some way so that we can see 
their connections' (1953: 4). Easton argues that the problem is not so much scientific theory but our misinterpretation of it, especially leaving out the theoretical cap stone. The present study continuously underlines the neglect of theory and the overemphasis on quantitative methodology and the amassing of data without adequate goals and models. We seem to have gone in the opposite direction from that proposed by Easton so that, combined with excessive specialization, the discipline has become increasingly irrelevant.

To dig a little deeper, we must ask: what is the behaviour driving these tendencies in political science? A number of recent studies put the finger on what I will call 'careerism' (Paquet, 2009) uses other terms like 'disciplinary reductionism, the credentialized tribe, and the professionalization of the academy' (see also Ricci, 1984). One does not have to be a conspiracy theorist to recognize a number of self-reinforcing norms and processes within the modern academy. To achieve tenure, promotion and continuing academic respectability, scholars must publish. The easiest path is via articles or chapters in international, peer-reviewed publications. These are the same peers with whom we cooperate at specialized national and international conferences. Publications must respect 'scientific' norms collectively established by disciplinary associations, journals and university departments. These norms are enforced by juries of peers. This closes the circuit because the credentialized peers are drawn from the same pool with which one has been interacting throughout the process. The circle is complete. There are no goals or standards beyond 'contributing to knowledge', no necessity to make connections with broader bodies of knowledge, and no requirements to communicate outside the circle of specialists. The pressure is towards mediocrity rather than imagina- tion. This is the process that fosters specialization, reinforcement of current fads and ivory-tower irrelevance. Obviously there are many exceptions to the rule - but it is the rule. No one person or group can change this practice. To break out of the circle will require a generalized consciousness of its pernicious effects and a collective desire to do something about. But it might start with a requirement that research publications make contributions to explaining and resolving human problems and/or expanding human wisdom, theory, and ethical norms.

But there is something we, as individuals, can do about our research. Let us call it 'rebalancing'. First, this means giving science a balanced position within the panoply of political studies. The aim would be to keep the best of the scientific approach while getting rid of scientific pretensions. Few would debate the contributions of the scientific method to our discipline: rigour, explanation of empirical regularities, precise observation based on measurement, rules of inference and replicability, normative controls, testing of hypotheses, etc. Simultaneously, we should correct some of our abuses of the scientific method by a return to the search for synthetic and causal general theory that Bear Braumoeller calls for in his article on 'Rediscovering Complexity and Synthesis' (Braumoeller, 2009: 241-243). Therefore, let us rigorously measure what can be measured, and give up the false pretension that all politics can be quantified or that it can be value-free or that all knowledge is empirical. As a symbol of 'rebalancing', our departments and associations should return to the earlier name of our discipline as 'political studies' at the same time as we join the other social science disciplines in calling ourselves 'politists'.

The second step in 'rebalancing' would be to take out of the drawer all the 
progressive moves that have been made in the past 50 years, but are now put aside in favour of faddish, narrow conceptions. I am thinking of bringing back to the fore systems theory, behavioural theory, normative theory, historicalinstitutionalism, critical theor and policy studies. Each one of us can add to the list. The movement in the United States towards 'qualitative and multi-methods' is part of the search for a better balance within the discipline. Further rebalancing can be attained by opening ourselves once again to knowledge from other socially relevant disciplines at the same time as we open our students to the real world through periods of practical placement of students in the work environment.

In a recent article on 'The Question of Relevance', Joseph Nye cites Robert Putnam's presidential address to the APSA, 'simple questions about major real world events have driven great research. Worrying about the same "big issues" as our fellow citizens is not a distraction from our best professional work, but often a goad to it' (Nye, 2009: 253). In practical terms, Stephen Walt (2005) has argued in The Annual Review of Political
Science for a conscious effort to alter the prevailing norms of the discipline. Departments should give greater weight to real-world relevance in hiring and promotion decisions; journals could place greater weight on relevance in evaluating submissions; universities could facilitate interest by giving junior faculty greater incentives for participating in political life.

When faced by these same questions of changing the discipline 25 years ago, David Ricci concluded that 'There is no reason to believe that the nation's great learning institutions, and the departments of political science they contain, are about to abandon science for another road to knowledge' (1994: 292). He called on students and professors to practice 'deception' (Plato's 'noble lie'?) by achieving status and then measuring their research 'against the widest possible background of human needs and convictions' (ibid.: 308 ). Surely a more promising proposal is to put the responsibility for rebalancing and relevance where it belongs - at the summit of our discipline. The executives of our associations should provide the leadership required to rejuvenate political studies.

\section{Note}

1 This report, as well as the programme to the IPSA Conference, can be found on my website, www.johntrent.ca.

\section{References}

Andreski, S. (1974) Social Sciences as Sorcery, Harmondsworth: Penguin.

Baldersheim, H. and Wollmann, H. (eds.) (2006) 'Assessment of the Field of Comparative Local Government and a Future Research Agenda', in The Comparative Study of Local Government and Politics: Overview and Synthesis, Opladen: Barbara Burdich Publishers, p. 122.

Braumoeller, B.F. (2009) 'Rediscovering Complexity and Synthesis', in G. King, K.L. Schlozman and N.H. Nie (eds.) The Future of Political Science: 100 Perspectives, New York: Routledge, p. 242.

Campbell, A., Converse, P.E., Miller, W.E. and Stokes, D.E. (1960) The American Voter, New York: John Wiley and Sons.

Coen, D., and Grant, W.(eds.) (2006) Business and Government: Methods and Practice, Opladen: Barbara Budrich Publishers.

Dahl, R.A., Bewley, T.F., Rudholph. S.H., and Mearshimer, J. (2004) 'What Have We Learned', in I. Shapiro et al (eds.) Problems and Methods in the Study of Politics, Cambridge: Cambridge University Press, pp. 379-381. 
Dwivedi, O.P. (2007) 'In the Matter of Good Governance: A Non-Western Perspective', in R.B. Jain (ed.) Governing Development across Cultures: Challenges and Dilemmas of an Emerging Sub-discipline in Political Science, Opladen: Barbara Budrich publishers, p. 184.

Easton, D. (1953) The Political System: An Inquiry into the State of Political Science, New York: Alfred A. Knopf.

Eisfeld, R. (ed.) (2006) Pluralism: Developments in the Theory and Practice of Democracy, Opladen: Barbara Budrich Publishers.

Flyvbjerg, B. (2001) Making Social Sciences Matter, Cambridge: Cambridge University Press.

King, G., Schlozman, K.L. and Nie, N.H. (eds.) (2009) The Future of Political Science: 100 Perspectives, New York: Routledge.

Lasswell, H.D. (1951) 'The Policy Orientation', in D. Lerner and H.D. Lasswell (eds.) The Policy Sciences, Stanford: Stanford University Press.

Lindblom, C.E. (1992) Inquiry and Change: The Troubled Attempt to Understand and Shape Society, New Haven, CT: Yale University Press.

Linz, J.J. (2007) 'Some Thoughts on the Victory and the Future of Democracy', in D. Ber-Schlosser (ed.) Democratization: The State of the Art, Opladen: Barbara Budrich Publishers, p. 145.

Lyon, A.J. (2008) 'Rejecting one's protégé: American media, public opinion and the UN', Paper prepared for presentation at the 2008 Conference of the International Studies Association, San Francisco.

Maxwell, N. (1984/2007) From Knowledge to Wisdom: A Revolution for Science and the Humanities, Oxford: Pentire Press.

Mitra, S.K. , Pehl, M. and Spiess, C.(eds.) (2009) Political Sociology: The State of the Art, Opladen: Barbara Budrich Publishers.

Munck, G.L. (2007) 'Democracy Studies: Agendas, Findings, Challenges', in D. Berg-Schlosser (ed.) Democratization: The State of the Art, Opladen: Barbara Budrich Publishers, p. 51.

Nye Jr, J.S. (2009) 'The Question of Relevance', in G. King, K.L. Schlozman and N.H. Nie (eds.) The Future of Political Science: 100 Perspectives, New York: Routledge, p. 253.

Paquet, G. (2009) Crippling Epistemologies and Governance Failures, Ottawa: University of Ottawa Press.

Ricci, D.M. (1984) The Tragedy of Political Science: Politics, Scholarship, and Democracy, New Haven, CT: Yale University Press.

Shapiro, I., Smith, R. and Masoud, T. (eds.) (2004) Problems and Methods in the Study of Politics, Cambridge: Cambridge University Press.

Shepherd, L. (ed.) (2006) Political Psychology, Opladen: Barbara Budrich Publishers, p. 133.

Shepsle, K. (2009) 'Why?', in G. King, K.L. Schlozman and N.H. Nie (eds.) The Future of Political Science: 100 Perspectives, New York: Routledge, p. 244.

Sylvan, D.A. and Strathman, B. (2006) 'The Political Psychology and the Study of Foreign Policy Decision Making', in L. Shepherd (ed.) Political Psychology, Opladen: Barbara Budrich Publishers, p. 96.

Walt, S. (2005) 'The relationship between theory and policy in international relations', The Annual Review of Political Science 8: 23-48.

Weiss, T.G. (2009) 'What happened to the idea of world government?' International Studies Quarterly 53: 253-271.

Whitehead, L. (2007) 'Twenty-first Century Democratizations: Experience versus Scholarship', in D. Berg-Schlosser (ed.) Democratization: the State of the Art, Opladen: Barbara Budrich Publishers, p. 131.

Wilde, O. (1954/1891) 'The Soul of Man under Socialism', in H. Pearson (ed.) Selected Essay and Poems, London: Penguin. 


\section{APPENDIX}

\section{THE BOOK SERIES: THE WORLD OF POLITICAL SCIENCE: DEVELOPMENT OF THE DISCIPLINE 2006-2010}

This was a project adopted by the IPSA in 1998 to produce specialized studies on various sectors of the discipline. This research programme of Research Committee (RC) 33 on the 'Study of the Discipline' formulated an analytical approach and research model that was offered to other RC that desired to study their particular sub-field. To date, the RC 33 Book Series, edited by Michael Stein and John Trent, has produced seven books with three to come.

- Berg-Schlosser, D. (ed.) Democratization: State of the Art, 2nd rev. ed., 2007.

- Shepherd, L. (ed.) Political Psychology, 2006.

- Eisfeld, R. (ed.) Pluralism: Developments in the Theory and Practice of Democracy, 2006.
- Coen, D. \& Grant, W. (eds.) Business and Government: Methods and Practice, 2006.

- Baldersheim, H. \& Wollmann, H. (eds.), The Comparative Study of Local Government \& Politics, 2006.

- Jain, R.B. (ed.) Governing Development across Cultures: Challenges and Dimensions of an Emerging Sub-discipline in Political Science, 2007.

- Mitra, S.K., Pehl, M. and Spiess, C. (eds.) Political Sociology: The State of the Art, 2009.

The three forthcoming publications in the Series include:

- Guelke, A. (ed.) Politics and Ethnicity, (RC 14).

- Bayes, J. (ed.) Women and Politics, (RC $7 \& 19)$.

- Somit, A. and Peterson, S. Biology and Politics, (RC 12).

All books are published by Barbara Budrich Publishers, Opladen, Germany.

\begin{abstract}
About the Author
John E. Trent was Professor and former Head of the Department of Political Science at the University of Ottawa where he is currently a researcher in the Centre on Governance. In addition to being a professor, he has been Secretary Treasurer of the Canadian Political Science Association, President of the Societe quebecoise de science politique, Executive Director of the Social Science Federation of Canada, Secretary General of the International Political Science Association, and Chair of the Constitutional Committee of the International Social Science Council. He organized world congresses for the IPSA from 1979 to 2000. His main interest is change and reform in political institutions. Trent's latest book is Modernizing the United Nations System (Barbara Budrich Publishers 2007). He presently works on a world process for 'Planning a New U.N.'
\end{abstract}

